Session 3550

\title{
Electrical Engineering Technology Experiences for Kindergarten Students
}

\author{
Kevin Torres, Michele Casey \\ Penn State Erie, The Behrend College/Creekside Christian School
}

\begin{abstract}
An outreach project has been designed and implemented to provide kindergarten students with engineering technology experiences. In engineering education much has been done in outreach to middle school students and high school students. But very little is being done to reach out to K-6 and practically none for kindergarten students, especially in the field of engineering.
\end{abstract}

This paper describes electrical engineering technology experiences tailored for kindergarten students. The experiences are hands-on experiments with the hope that kindergartners can learn at-their-level fundamental electricity concepts. Knowledge of electricity theory through experiences is the end goal. One way this will be accomplished is by providing the students with first a concept, then asking them to make predictions. Introducing students to engineering at the kindergarten level is obviously a long term investment but what better a time to peak their interest and curiosity at such a vital age. The project also provides university faculty with the opportunity to serve the community.

\subsection{Introduction}

The primary goal of these experiences is to give kindergarten students engineering knowledge that they can claim as their own. One way to introduce students to EET is by seeing, reading, or by word of mouth. This provides the student with information on the topic. Another way to introduce students to this topic is by doing something with equipment, with their own hands, so they see, hear or feel something happen. This provides the students from their own experiences with knowledge of the topic ${ }^{1}$. And knowledge is the end goal. A paper from the ASEE 2000 annual conference inspired the outreach project to kindergarten students by Professor Angie HillPrice. In that paper ${ }^{2}$ Ms. Price shared how to introduce students to the field of material science. The concepts were then taken and applied to the field of electrical engineering technology. It is very common to introduce 9-12 grade students to engineering, however, very little is being done for the little people. Several papers ${ }^{2-15}$ claim to have programs for K-12, however, very little if anything is actually done for kindergarten students in these programs. Out of 51 published researched papers $^{2-53}$ dealing with engineering outreach from the 1998, 1999, and 2000 ASEE and 1998 and 1999 Frontiers In Education Annual conferences, only four papers ${ }^{2-5}$ target Kindergarten students. Also, there is no engineering curriculum for early-childhood education. Kindergarten teachers in public and private schools can be contacted for a visiting professor to conduct the project onsite. 


\subsection{Experience Goals}

Elements that are desired in the EET experiences are children interaction with the materials, their friends, and the teacher. We also want the children "to make their own predictions and test their predictions through interaction with materials ${ }^{54}$." Table 1 illustrates the goals set for each activity and the time frame in which it will presented.

\begin{tabular}{|l|l|l|}
\hline Activity & Goal & Time Frame \\
\hline Introduction & $\begin{array}{l}\text { Identify purpose of electricity } \\
\text { and safety }\end{array}$ & 10 minutes \\
\hline Current & Recognize that current flows & 5 minutes \\
\hline Voltage & $\begin{array}{l}\text { Voltage is the force behind the } \\
\text { current }\end{array}$ & 5 minutes \\
\hline Batteries & $\begin{array}{l}\text { Recognize as a source of } \\
\text { electricity }\end{array}$ & 5 minutes \\
\hline Conductors & $\begin{array}{l}\text { Identifying objects that allow } \\
\text { current to flow through }\end{array}$ & 5 minutes \\
\hline Insulators & $\begin{array}{l}\text { Identifying objects that do not } \\
\text { allow current to flow through }\end{array}$ & 5 minutes \\
\hline Resistors & $\begin{array}{l}\text { Recognize as restricting the } \\
\text { flow of current. }\end{array}$ \\
\hline Activity pages & $\begin{array}{l}\text { Apply knowledge of } \\
\text { demonstrations }\end{array}$ \\
\hline
\end{tabular}

\section{Table 1. Experience Goals/Time Table}

From our literature research, we realized the significance of stressing the importance of math as a basic tool and its application to EET. With this in mind, we incorporated basic math skills of exploring, sorting, classification, and comparing and contrasting ${ }^{55}$.

\subsection{EET Experiences}

It was determined that the attention span of kindergarten students is approximately 10 to 15 minutes. With that in mind a variety of experiences were developed and presented to the students in order to maintain their interest of the subject. The concepts that we wanted to introduce to this group of students are current, voltage, batteries, conductors, insulators, and resistors. These topics are usually found in the 2 nd and/or third chapters of electric circuit textbooks ${ }^{56,57,58}$. In explaining these topics, simple language was used. However, technical terms were not avoided $^{2}$. In this way the students are introduced to science, engineering and engineering technology $\mathrm{y}^{2}$. An outline of the project is shown in Appendix A.

The circuit shown in Figure 1, which the students build, is used to introduce all the above mentioned topics. The Erie Engineering Societies Council provided funding for the

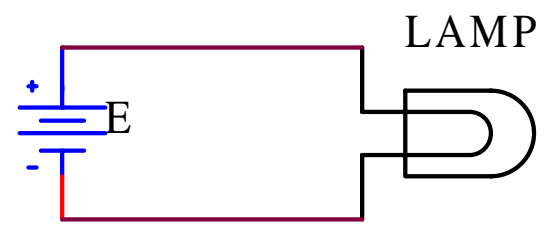

Figure 1. Basic Circuit components and props. A parts list for all the components is shown in Table 2. 


\begin{tabular}{|c|l|r|r|}
\hline QTY & Description & Price & Total \\
\hline & Radio Shack & $\$ 1.19$ & $\$ 16.66$ \\
\hline 14 & 272-1174 1.2V Bulb, 250 mA & $\$ 1.29$ & $\$ 5.16$ \\
\hline 4 & 272-360 Lamp Screw base(4) & $\$ 5.99$ & $\$ 23.96$ \\
\hline 4 & AA batteries (8 pack) & $\$ 1.09$ & $\$ 15.26$ \\
\hline 14 & $910-2966$ Battery Holder & $\$ 0.35$ & $\$ 19.60$ \\
\hline 56 & $910-0203$ Alligator clip w/ banana jack barrel & & \\
\hline & K-Mart & $\$ 9.99$ & $\$ 9.99$ \\
\hline 1 & 700 Piece Mega Block & $\$ 1.89$ & $\$ 1.89$ \\
\hline 1 & Play Doh & $\$ 0.95$ & $\$ 0.95$ \\
\hline 1 & Aluminum foil & $\$ 2.19$ & $\$ 2.19$ \\
\hline 1 & Zip lock bags & & \\
\hline & Media Play & $\$ 45.00$ & $\$ 90.00$ \\
\hline 2 & Thomas 5-car Value Pack & $\$ 40.00$ & $\$ 18.00$ \\
\hline 1 & Henry engine & & \\
\hline 1 & Figure eight train set & & $\$ 253.66$ \\
\hline & & & \\
\hline & & & \\
\hline
\end{tabular}

Table 2. Project Parts List

\subsection{Current}

Current is the flow of electrons. In direct current, "the electrons flow in one direction from the negative terminal of the battery to the positive terminal ${ }^{59}$." The analogy used to describe this water flowing through a straw. The students were asked what would happen if you blow in one of the straws. At this point in the demonstration the students were given their first experience. Figure 2 shows a boy and girl trying out their predictions.


Figure 2. Experience \#1 


\subsection{Voltage}

Voltage is the driving force that establishes current. The analogy used to describe this topic is the pressure that causes the water to flow from one bottle to another.

\subsection{Batteries}

As mentioned earlier, the battery is one source of electricity. It was decided that for kindergarten students the chemical reaction, which takes place inside the battery, would not be discussed. Instead, the capacity and series connection of AA and D size batteries was discussed. The series connection of batteries was introduced with the analogy of Thomas the Tank Engines ${ }^{\mathrm{TM}}$ pulling four freight cars. The Thomas train that comes with the "Figure Eight Train Set" has a "happy" expression. Next, eight freight cars are added to Thomas and the engine is switched with the Thomas that comes with the "hard at work" expression. The students were then asked what could be done to make Thomas' job easier. The answer is to connect two Thomas engines in series. Batteries connected in series to a light are like Thomas engines connected in series to freight cars. The capacity of batteries was also described by using different size engines like Thomas and Henry.

At this point in the demonstration the students were given their second experience. They were given a copy of the wiring diagram shown in Figure 3 and with supervision connected the circuit. Figure 4 shows the students building the circuit.

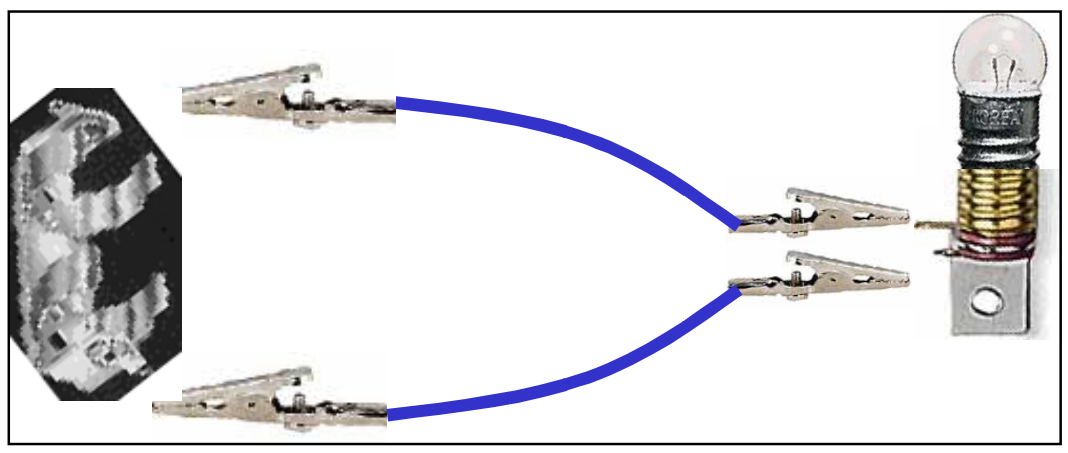

Figure 3. Experience \#2

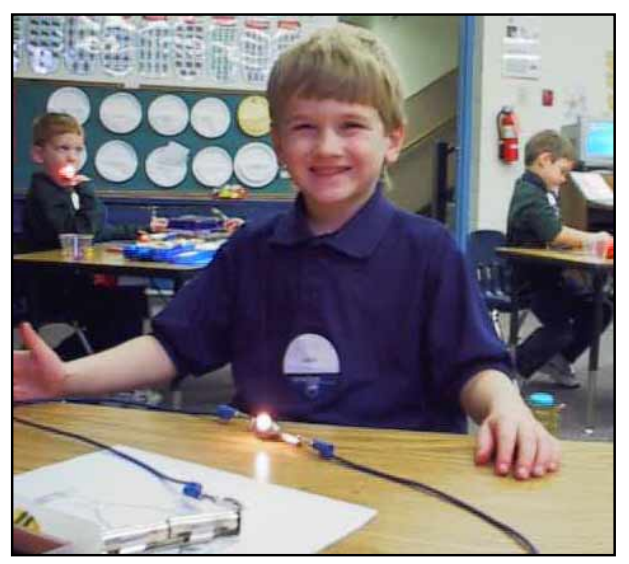

Figure 4. Students building circuit 


\subsection{Conductors}

Conductors allow for the flow of electrons. An example of a common conductor is copper or zinc. The students can be shown a penny. "Most metals are good conductors ${ }^{60}$." In order for electrons to flow there must be a path. Conductors provide that path. The wires used to connect the batteries to the light are conductors. Conductors are like the tracks of a train, which guide the train.

\subsection{Insulators}

Insulators do not allow for current to flow. Insulators are used to cover conductors and provide protection from electricity.

At this point in the demonstration the students were given their third experience. They were given a copy of the wiring diagram shown in Figure 5 and with supervision connected the circuit.

The students were provided with a paper clip, coins, aluminum foil, rubber band, Play-Doh, and Lego $^{\mathrm{TM}}$ block and asked to determine which are conductors and which are insulators.

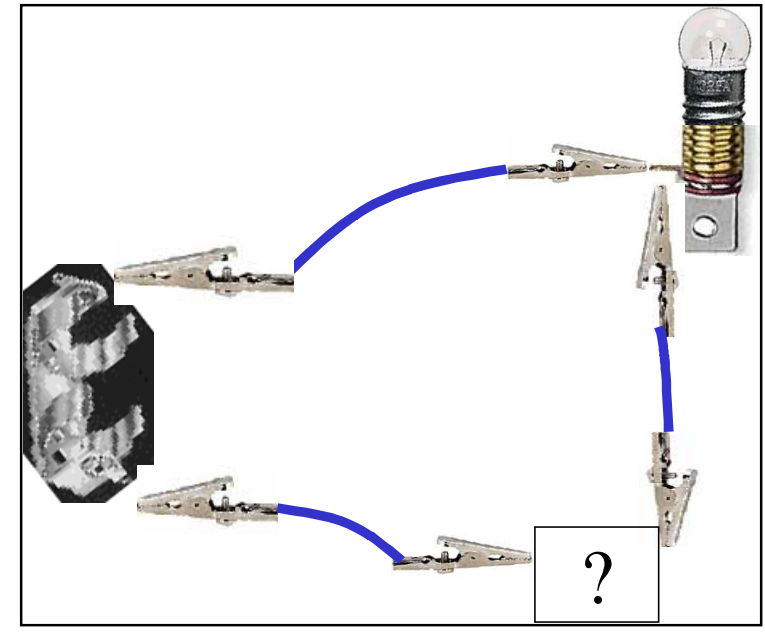

Figure 5. Experience \#3

\subsection{Resistors}

Resistors restrict or oppose the flow of current. One analogy that can be used to represent resistance is the valve in a faucet. If you ask a five-year old what the difference is between a high resistance and low resistance setting on the faucet a typical answer would be fast and slow. If you ask a five-year old what the difference is between a flat train track and an elevated train track a typical answer would be low and high. Both of these analogies describe resistance to current. If a resistor were added to our light circuit then the light would go dim. The relationship between resistance and current is as resistance increases then current decreases.

\subsection{Program Assessment}

Because of the age group, students will be assessed of the knowledge they obtain primarily on a performance basis. Students will demonstrate an understanding of the concepts introduced by successfully participating in the above mentioned activities. In order to obtain sufficient feedback from the students to gauge understanding, students will be asked to retell various demonstrations that they witness. In addition to the performance assessment, students will also be evaluated using activity pages where they will categorize objects into two classes depending on the criteria. 


\subsection{Test for electricity}

To demonstrate their knowledge of electricity, students will identify items in their home that require electricity to function. Each student will complete an activity page, shown in Appendix $\mathrm{B}$, containing illustrations of objects in the home and will differentiate between the items that use electricity and those that do not require any.

\subsection{Test for current}

Students will show an understanding of current by participating in the relevant activities and making accurate predictions using the knowledge they obtain. The main point that the students will comprehend is that current flows.

\subsection{Test for voltage}

For this age group, the focus of the voltage demonstration will be that voltage is like "power." The class will demonstrate an understanding of this concept by making accurate predictions regarding the role of voltage during the activities.

\subsection{Test for batteries}

Through the activity, students will demonstrate an understanding that by adding multiple batteries, or batteries with larger voltage, they will obtain more "power" to light the bulb.

\subsection{Test for conductors}

Using a trial and error method, students will investigate various objects and categorize them to be conductors or insulators. To demonstrate knowledge of this skill, students will extend what they learned and applied to other objects as well by completing the activity page, shown in Appendix C, consisting of conductors or insulators.

\subsection{Conclusion}

The students were very enthusiastic regarding the project and were focused and interested throughout the demonstrations and activities. Also, the class was attentive and listened well to the directions being given. All nine students successfully completed each of the activity pages independently and demonstrated their ability to apply the knowledge they obtained from the activities. The hands on activities of building a circuit and testing conductors helped the students to feel successful in applying their knowledge when they built a complete circuit and generated light. Not only was the objective of introducing the students to electrical engineering achieved, but the class also communicated an enthusiasm for it. The activities and presentation provided an opportunity for the students to interact with electricity. At this age, children view electricity as something abstract but through their participation they were able to understand it more concretely. During the demonstration, students not only asked questions regarding what was being presented, but extended that to ask questions pertaining to electricity in general. For example one student was curious as to how a light could work if it is not "plugged into the wall". Through the explanation and demonstration of batteries, voltage and current, the student now 
understands how batteries are the power source for her toys and light. Hopefully through this project the children are now aware of science, engineering and technology.

A week after the lesson, the electricity at the school failed one afternoon. The teacher took this opportunity to review what the class had learned about electricity. The students were quick to classify items in the school that could not be used because of the lack of electricity. When the teacher pointed out the emergency lighting in the building, one student concluded that those lights would have to run on batteries since there was not any electricity. This proved that the students had developed a base knowledge of electricity and were able to apply that information in other setting and situations.

\subsection{Future Recommendations}

Two related improvements will be implemented for future kindergarten projects. Some of the students found the alligator clips difficult to connect because of the force required to open them. Also, three of the nine students accidentally shorted the two AA battery pack with one wire. When this occurred the batteries short circuit and became very hot. This did however provided a practical lesson on safety when working with electricity. In the introduction of the lesson, safety was a key factor discussed, specifically having adult supervision, and caution regarding outlets and wires. This incident was a perfect illustration of points discussed earlier. In order to avoid both of these conditions we propose that the wires be connectorized with banana jacks and plugs. This will make it easier for the students to hook-up and would eliminate the possibility of connecting the parts incorrectly.

Bibliography

${ }^{1}$ Science Experiences with Inexpensive Equipment, Carleton Lynde, D. Van Nostrand Company, 1950, p v

${ }^{2}$ Hill Price, Angie, "Recommendations for Establishing Small Scale K, 1 Outreach", Proceedings 2000 ASEE

Annual Conference.

${ }^{3}$ Sappington, Teresa, Toghiam, Rebecca K., "SEE for Kids: K-6 Outreach Efforts at Mississippi State University", Proceedings 2000 ASEE Annual Conference.

${ }^{4}$ Bottomley, Laura J., Parry, Elizabeth A., "Beyond the Classroom Walls: Relating Science to Children's Everyday Lives", Proceedings 2000 ASEE Annual Conference.

${ }^{5}$ Burghardt, M. David, "Developing the Field of Children's Engineering", Proceedings 2000 ASEE Annual Conference.

${ }^{6}$ Tsang, Edmund, Newman, E. Jean, "Service-Learning's Effect on Engineering Students and K-12 Teacher Partnership in an "Introduction to Mechanical Engineering" Course," Proceedings of the Frontiers in Education Conference, pp. 1279-1282, 1998.

${ }^{7}$ Sullivan, Jacquelyn F., Davis, Steven E., deGrazia, Janet L., Carlson, Denise W., "Beyond the Pipeline: Building a K-12 Engineering Outreach Program," Proceedings of the Frontiers in Education Conference, pp. 11 b5-21 - 11b526, 1999.

${ }^{8}$ Sechrist, Chalmers, Anagnostopoulos, Constantine, Lewis, Peter, Coburn, Barbara, “Technological Literacy Counts: Outcomes of a Workshop to Enhance Technological Literacy of K-12 Students," Proceedings of the Frontiers in Education Conference, pp. 1273, 1998.

${ }^{9}$ Poole, Susan J., deGrazia, Janet L., Sullivan, Jacquelyn F., “Assessing K-12 Pre-Engineering Outreach Programs," Proceedings of the Frontiers in Education Conference, pp. 11b5-15 - 11b5-20, 1999.

${ }^{10}$ Carr, James R., "Suggestions for Using Satellite Images in K-12 Education," Proceedings of the Frontiers in Education Conference, pp. 11b5-1 - 11b5-7, 1999.

${ }^{11}$ Anderson-Rowland, Mary R., Reyes, Maria A., Jordan, Cathryne, McCartney, Mary Ann, "A Model for Academia, Industry, and Government Collaboration for K-12 Outreach," Proceedings of the Frontiers in Education Conference, pp. 13a7-2 - 13a7-7, 1999.

${ }^{12}$ Erwin, Ben, "K-12 Education and Systems Engineering: A New Perspective", Proceedings 1998 ASEE Annual Conference. 
${ }^{13}$ Adams, Barbara, Bruning, Monica, Genalo, Lawrence J., "Creating a K-12 Engineering Educational Outreach Center", Proceedings 1999 ASEE Annual Conference.

${ }^{14}$ Fadali, M.Sami, McNichols, K., Robinson, Mike, "Teaching Engineering to K-12 Students Using Role Playing

Games", Proceedings 1999 ASEE Annual Conference.

${ }^{15}$ Severance, Charles, Moore, Tricia, "Making Virtual Reality Worlds - Interaction Between Higher Education and K-12," Proceedings of the Frontiers in Education Conference, pp. 13b6-12, 1999.

${ }^{16}$ Anwar, Sohail, "A Contemporary Science and Engineering Program for Middle School Girls", Proceedings 2000 ASEE Annual Conference.

${ }^{17}$ Sukumaran, Beena, Jahan, Kauser, Keil, Zenaida O., Head, Linda M., "AWE: An Outreach Workshop for Middle School Girls", Proceedings 2000 ASEE Annual Conference.

${ }^{18}$ Horan, Shelia, "Encouraging More Science in the Elementary School", Proceedings 2000 ASEE Annual

Conference.

${ }^{19}$ Cooney, Elaine M., Mueller, Arlene, "Logic to Electronics: A Teaching Unit for Elementary Students", Proceedings 2000 ASEE Annual Conference.

${ }^{20}$ Lee, Lang Wah, Ceylan, Tamer, "Strengthening the Pipeline - A Workshop for Middle School Mathematics and Science Teachers", Proceedings 2000 ASEE Annual Conference.

${ }^{21}$ Sharp, Janet M., Chandler, Tracy L., Petersen, John A., "Teaching Teachers to Apply Engineering: A Tale of Two High School Classrooms", Proceedings 2000 ASEE Annual Conference.

${ }^{22}$ Hanna, Evelyn, "The Academy at Rutgers for Girls in Engineering and Technology (TARGET)", Proceedings 2000 ASEE Annual Conference.

${ }^{23}$ Musto, Joseph C., Howard, W.Ed, Rather, Stephen, "The RP Derby: A Design/Build/Test Expereince for High School Students", Proceedings 2000 ASEE Annual Conference.

${ }^{24}$ Reid, Kenneth J., "The Young Scholars Summer Program in Electronics and Computers", Proceedings 2000 ASEE Annual Conference.

${ }^{25}$ Speaks, Rachel, "Hands-on Engineering for High School Students", Proceedings 1998 ASEE Annual Conference.

${ }^{26} \mathrm{McMillian}$, Dominique, "Introducing High School Students to the field of Civil Engineering: The ASCE/MESA Summer Institute", Proceedings 1998 ASEE Annual Conference.

${ }^{27}$ Burtner, Joan, Relyea, Lara, "Using K'NEX to Stimulate Interest in Engineering at a Summer Camp for Middle School Students", Proceedings 1998 ASEE Annual Conference.

${ }^{28}$ Adelson, Gary, Blais, Richard, "Project Lead the Way - A Model Program for Initiating, Funding and Maintaining a Successful Pre-Engineering Program in the Nation's High Schools," Proceedings of the Frontiers in Education Conference, pp. 1161-1165, 1998.

${ }^{29}$ Robinson, M., Fadali, M. Sami, “A Model to Promote the Study of Engineering through a Capstone Course for Pre Service Secondary Science and Mathematics Teachers," Proceedings of the Frontiers in Education Conference, pp. 1166-1171, 1998.

${ }^{30} \mathrm{Ma}$, Joyce, “A Computer-Based Learning Environment Education for Teaching High-School Students Feedback Control through Design ," Proceedings of the Frontiers in Conference, pp. 1172, 1998.

${ }^{31}$ Anwar, Sohail, "A Contemporary Science and Engineering Education Program for $8^{\text {th }}$ and 9 th Grade Students," Proceedings of the Frontiers in Education Conference, pp. 1173-1177, 1998.

${ }^{32}$ Beston, William, "ASL and ES Delivering a Complete 2-Yr Engineering Science Curriculum in Asynchronous Mode," Proceedings of the Frontiers in Education Conference, pp. 1178, 1998.

${ }^{33}$ Cook, Robert, "A Web-Based C++ Course Project," Proceedings of the Frontiers in Education Conference, pp. 1272-1273, 1998.

${ }^{34}$ Beauchamp-Baez, Gerson, Cruz-Rivera, Jose, Lugo-Beauchamp, W., "The Pre-College Engineering Program at the University of Puerto Rico-Mayaguez: Methods of Assessment," Proceedings of the Frontiers in Education Conference, pp. 1274-1278, 1998.

${ }^{35}$ Blot, Kevin, Della-Piana, Gabriel, Turner, Wyona, "The Development and Employment of Formative Evaluation Instruments to Enhance Students' Opportunity to Learn," Proceedings of the Frontiers in Education Conference, pp. 1355-1360, 1998.

${ }^{36}$ Bruck, Hugh, Rocheleau, David, Rogers, Craig, "Development of Statewide Engineering Head Start Program," Proceedings of the Frontiers in Education Conference, pp. 1361-1364, 1998.

${ }^{37}$ Genalo, Lawrence, Wright, Charles, Wright, Kara, "Toying With Technology in Elementary Education," Proceedings of the Frontiers in Education Conference, pp. 1365, 1998.

${ }^{38}$ Carlson, Patrica A., "Enabling Academic Excellence in Middle Schools Through Computer-Mediated Learning," Proceedings of the Frontiers in Education Conference, pp. 11b5-8, 1999.

${ }^{39}$ Lang, R. Raymond, Saacks-Giguette, Marguerite, "Introducing High School Student to Event Driven Programming," Proceedings of the Frontiers in Education Conference, pp. 11b5-9 - 11b5-14, 1999. 
${ }^{40}$ Samson, Perry, Brooks, Thomas, Cole, David, Cruz, Mathew, Dulin, Charles, Kim, Philip, "Internet-Activated Multimedia as A Distance Learning Alternative," Proceedings of the Frontiers in Education Conference, pp. 11b527, 1999.

${ }^{41}$ Schulte, Michael, Power, Christopher, Andrews, Corey, Hamilton, Tysha, Muniz, Wilmarie, Haileselassie, Hiriti, Haileselassie, Welela, Mlodossich, Keli, Leveque, Christina, Smith, Erika, Bristol, Adfia, "National Society of Black Engineers Community Outreach Program," Proceedings of the Frontiers in Education Conference, pp. 12d41 - 12d4-6, 1999.

${ }^{42}$ Fletcher, Shawna, White, Mary Aleta, Anderson-Rowland, Mary R., "Design and Implementation of Engineering Projects for the Women in Applied Science and Engineering (WISE) Summer Recruiting Programs," Proceedings of the Frontiers in Education Conference, pp. 12d4-13 - 12d4-19, 1999.

${ }^{43}$ Hanesian, Deran, Perna, Angelo J., "Introducing $6^{\text {th }}$ to $12^{\text {th }}$ Grade Students in K to 12 Programs to Science and Engineering through Expermental Measurements," Proceedings of the Frontiers in Education Conference, pp. 12d4-20 - 12d4-25, 1999.

${ }^{44}$ Lau, Kin W., Tang, Heng Klat, Erwin, Benjamin T., Petrovic, Pavel, "Creative Learning in School with LEGO Programmable Robotics Products," Proceedings of the Frontiers in Education Conference, pp. 12d4-26, 1999.

${ }^{45}$ Whitton, Sharon, "Leadership in Integrating Math, Science and Technology in the Elementary School,"

Proceedings of the Frontiers in Education Conference, pp. 13a7-1, 1999.

${ }^{46}$ McNichols, Kenneth H., Fadali, M. Sami, "The Classroom Computer: A Role-Playing Educational Activity,"

Proceedings of the Frontiers in Education Conference, pp. 13a7-8 - 13a7-13, 1999.

${ }^{47}$ Blake Bath, Barbara, "C2 for Mathematics Teachers," Proceedings of the Frontiers in Education Conference, pp. 13a7-18 - 13a7-19, 1999.

${ }^{48}$ Robinson, Mike, Fadali, M. Sami, Maddux, C., "Engineering Principles for High School Students," Proceedings of the Frontiers in Education Conference, pp. 13a7-20, 1999.

${ }^{49}$ Vann-Hamilton, Joy, Marsh, Dana, “A Two-Way Interactive Video Pre-College Engineering Program: The Notre Dame Model," Proceedings of the Frontiers in Education Conference, pp. 13b6-1 - 13b6-4, 1999.

${ }^{50}$ Pappas, Constantine, "On Generating Scientific Maturity," Proceedings of the Frontiers in Education Conference, pp. 13b6-5 - 13b6-7, 1999.

${ }^{51}$ Kimmel, Howard, O'Shea, Mark, "Professional Development and the Implementation of Standards," Proceedings of the Frontiers in Education Conference, pp. 13b6-8 - 13b6-11, 1999.

${ }^{52}$ Petry, Elizabeth, "Architectural Education: Meeting the Challenges," Proceedings of the Frontiers in Education Conference, pp. 13b6-13 - 13b6-16, 1999.

${ }^{53}$ Lord, Susan M., "Service-Learning in Introduction to Engineering at the University of San Diego: First Lessons," Proceedings of the Frontiers in Education Conference, pp. 13b6-17, 1999.

${ }^{54}$ Science Experiences for Young Children: Magnets, Rosemary Althouse, Cecil Main, Teachers College Press, 1975, p1

${ }^{55}$ Pierson Edward, Johnson Nancy, "A Precollege Engineering and Science Summer Program", Proceedings 2000 ASEE Annual Conference.

${ }^{56}$ Boylestad, Robert L., Introductory Circuit Analysis, Prentice-Hall, 2000.

${ }^{57}$ Robbins, Allan H., Miller, Wilhelm C., Circuit Analysis, Delmar, 1999.

${ }^{58}$ Floyd, Thomas L., Electronic Fundamentals, Prentice-Hall, 2001.

${ }^{59}$ Macaulay, David, The Way Things Work, Houghton Mifflin, p 287, 1998.

${ }^{60}$ Floyd, Thomas L., Electronic Fundamentals, Prentice-Hall, p31, 2001.

\section{KEVIN TORRES}

Kevin M. Torres is a Lecturer in Engineering at Penn State Erie. He received his B.E.E. degree (Cum Laude) from Auburn University in 1990 and his M.S.E.E. degree from Georgia Institute of Technology in 1996. Prior to joining the faculty at Penn State Erie in 1998, he worked at Georgia Tech Research Institute as a research engineer for eight years. His interests include high-density electronic packaging and embedded microcontroller design.

\section{MICHELE CASEY}

Michele Casey is a kindergarten teacher at Creekside Christian School in North East, Pennsylvania. She received her B.S. degree in Elementary Education from Edinboro University of Pennsylvania in 1995. 


\section{Appendix A}

\section{Teaching Instruction Table}

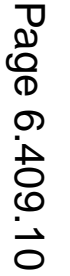




\begin{tabular}{|c|c|c|}
\hline Experience & Procedure & Materials \\
\hline Current \& Voltage & $\begin{array}{l}\text { Introduce analogy that current flows } \\
\text { like water through a straw. Students } \\
\text { will predict what will happen to the } \\
\text { water in the flask when they blow } \\
\text { through one straw. Test prediction. } \\
\text { Explain voltage as the power that } \\
\text { you blow through the straw. } \\
\text { (See Figure 2, Experience1) }\end{array}$ & Straws, flask, water \\
\hline Battery Capacity & $\begin{array}{l}\text { Draw analogy between trains and } \\
\text { batteries. When an engine pulls } 4 \\
\text { cars, it is able to work at a normal } \\
\text { pace. Add } 4 \text { more cars to the train. } \\
\text { The engine now must work harder to } \\
\text { pull twice as many cars. Discuss } \\
\text { what can be done to make the job of } \\
\text { the engine easier. Solution is to } \\
\text { have two engines in series. Explain } \\
\text { that batteries connected in series is } \\
\text { the same as the train engines. }\end{array}$ & Thomas Tank Engine Set \\
\hline Circuit Building & $\begin{array}{l}\text { By attaching two wires with alligator } \\
\text { clips to battery holder (with } \\
\text { batteries) and to lamp base (with } \\
\text { bulb) a complete circuit is } \\
\text { constructed. (See Figures } 3 \text { and 4) }\end{array}$ & $\begin{array}{l}2 \text { alligator clips with wire, lamp } \\
\text { screw base, } 1.2 \mathrm{v} \text { bulb, battery } \\
\text { holder, } 2 \text { AA batteries }\end{array}$ \\
\hline Conductors and Insulators & $\begin{array}{l}\text { Students add a third wire and } \\
\text { alligator clip to their circuit. (See } \\
\text { Figure 5) Using a trial and error } \\
\text { method, students will determine } \\
\text { objects to be conductors or } \\
\text { insulators by connecting the object } \\
\text { to the banana clips and observing if } \\
\text { the bulb turns on. }\end{array}$ & $\begin{array}{l}\text { Alligator clip and wire, Paper clip, } \\
\text { coins, aluminum foil, rubber band, } \\
\text { Play-Doh, Lego }\end{array}$ \\
\hline
\end{tabular}




\section{Appendix B}

\section{Electricity Activity Page}

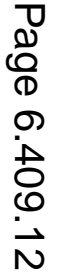


Name

Circle the objects that use electricity.
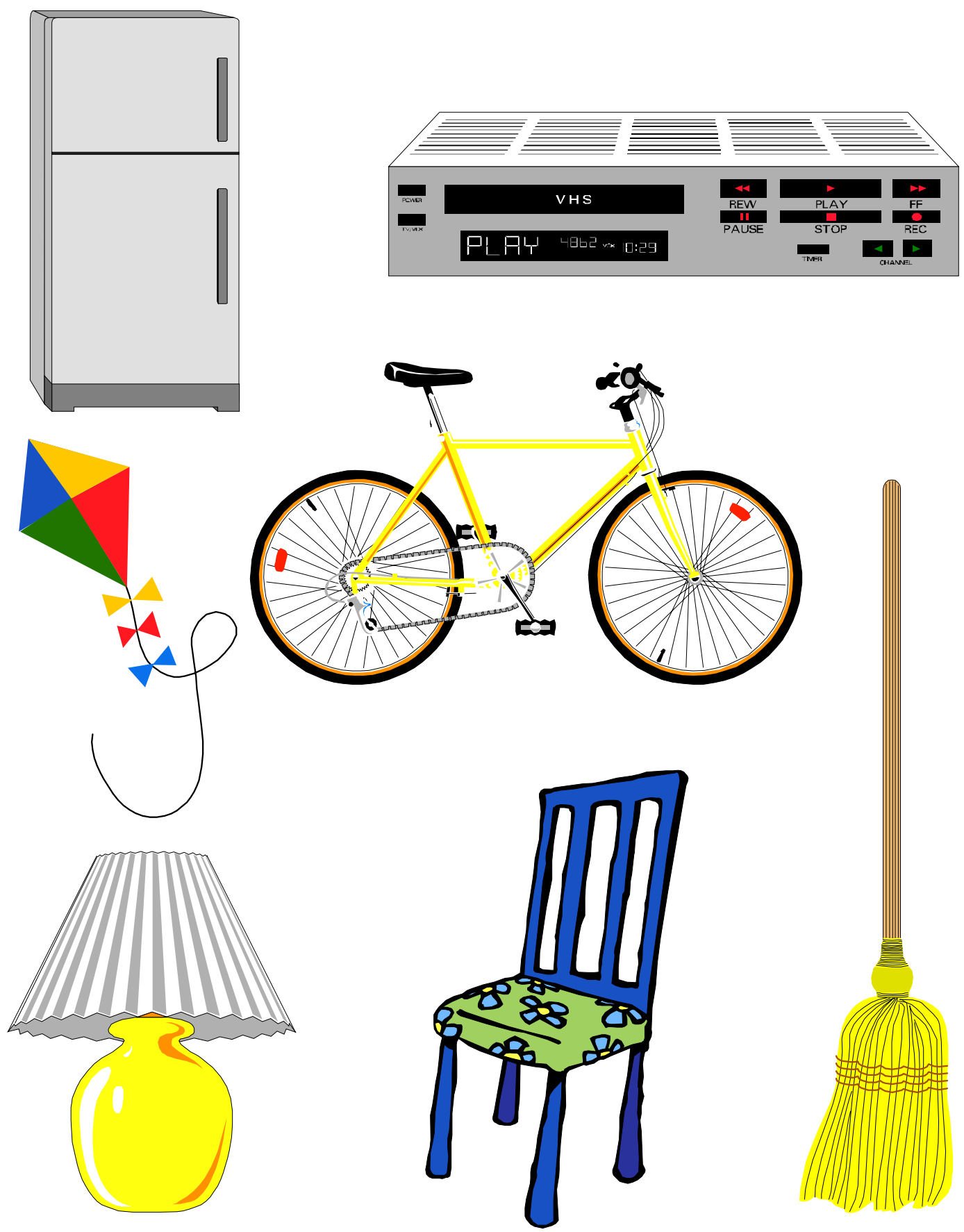

Proceedings of the 2001 American Society for Engineering Education Annual Conference \& Exposition Copyright (C) 2001, American Society for Engineering Education 


\section{Appendix C}

\section{Conductor Activity Page}

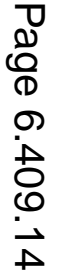


Name

\section{Circle the items that are conductors}

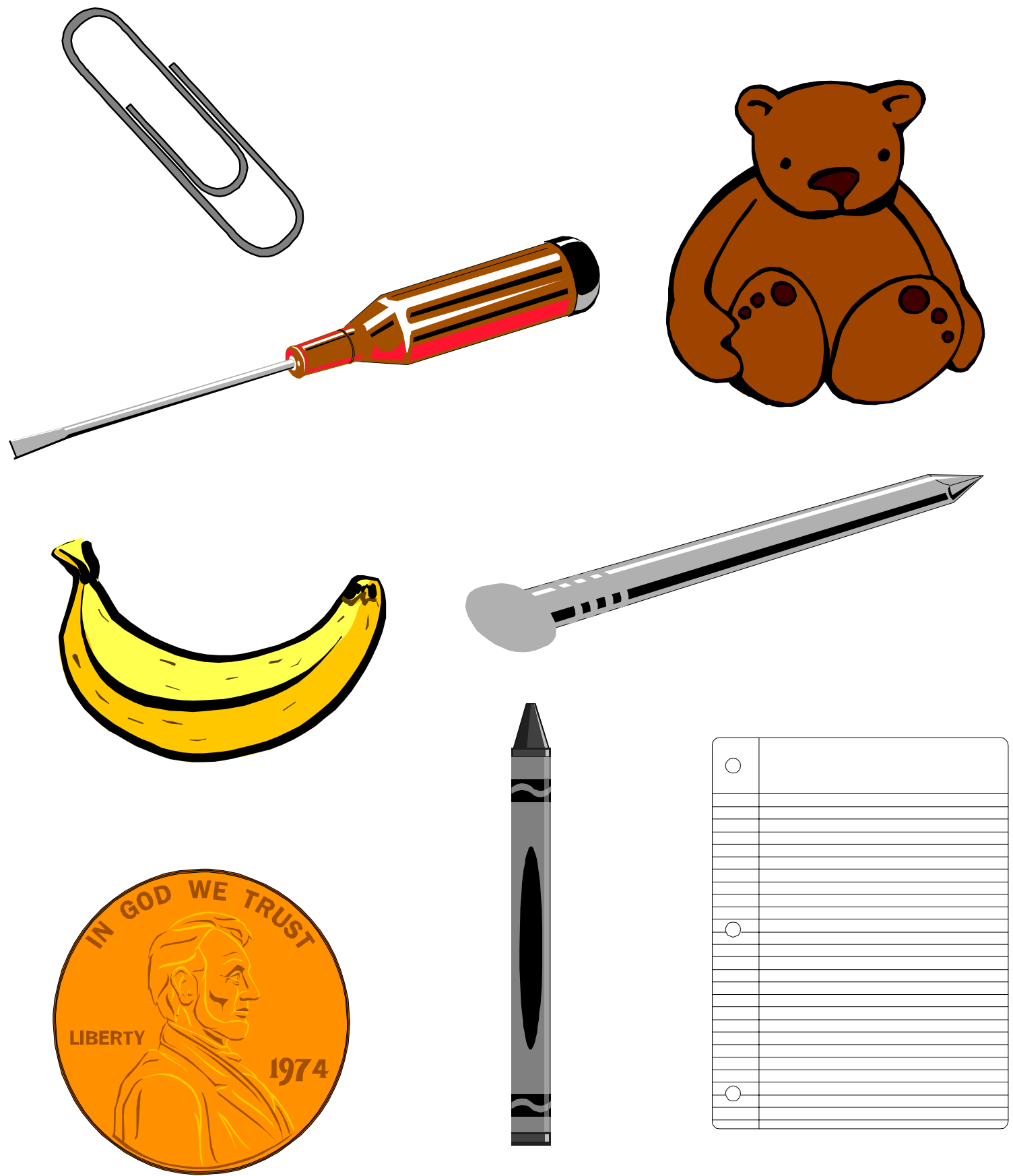

